\title{
India and Trinidad \& Tobago: Diaspora Building and Diaspora Integration - Implications for Emigration States
}

\section{Susan Julia Chand}

\begin{abstract}
India had influenced the community life of people of Indian origin in Trinidad \& Tobago long before diplomatic relations commenced between the two nations in 1948. This paper is an attempt to provide a historical description of the state-diaspora relations between India and Trinidad \& Tobago during and post indentureship. The paper draws from the written accounts by historians, government officials and scholars on the policies applied to the indentureship system, abolition, and bilateral relations between the two nations. Gamlen's (2008) two diaspora mechanisms are employed to demonstrate the statediaspora relations. The major findings indicate that the early Indian migrants developed mechanisms to cultivate a diaspora identity based on their collectively created vision of 'an imagined India'. Additionally, diaspora building and diaspora integration in post indentureship through numerous cultural exchange programs and educational opportunities for IndoTrinidadians and Indian nationals have been top-most in forging diplomatic relations between the two nations. In the final analysis, there is a need for a more in-depth analysis of Gamlen's diaspora mechanisms and the model of emigration state typology and how these can apply to the Indian diasporas in the Caribbean.
\end{abstract}

Keywords: diaspora mechanisms, indentureship, Indian Diaspora, nationdiaspora relations, emigration 


\section{Introduction}

India and the Republic of Trinidad \& Tobago have enjoyed vibrant bilateral relations for over 70 years since the establishment of the Indian Mission in TRINIDAD \& TOBAGO's capital city in Port of Spain in July 1948. It was one of India's first diplomatic relations established in the Caribbean region following its Independence from British rule. However, according to the Special Report on India and Trinidad \& Tobago (2014:8),

The relationship between India and Trinidad \& Tobago started on 30 May 1845, when the first ship 'Fatel Razack' carrying 225 indentured workers from India reached the shores of Trinidad, then a British colony. Their numbers increased with the subsequent arrival of more ships from India. The descendants of those workers, now in their fifth generation are part and parcel of the economic, political and social fabric of the country. They have maintained their traditional Indian cultural and religious customs. The presence of a substantial population of Indian origin (the largest ethnic group) has contributed greatly to bilateral relations between the two countries.

On August 6, 1962, soon after TRINIDAD \& TOBAGO's Independence, India's first High Commissioner was appointed and in the same year, TRINIDAD \& TOBAGO opened their High Commission in New Delhi.

Located about 14 kilometers north of Venezuela in South America, TRINIDAD \& TOBAGO displays an interesting landscape of a culturally diverse and mixed population. The current population is 1,328,019 comprising mainly East Indians (35.4\%) and Africans (34.2\%). Other ethnic groups exist in small percentages like Caucasian $(0.59 \%)$, Chinese $(0.30 \%)$, Indigenous $(0.11 \%)$, Syrian/Lebanese $(0.08 \%)$, Portuguese $(0.06 \%)$ and other ethnic groups $(0.17 \%)$ (Trinidad \& Tobago 2011 Population and Housing Census Demographic Report 2012: 2, 5). The East Indians (as they are now called) are descendants of Indentured laborers that were brought to work in the sugar plantations from India under the British regime during the period 1845 - 1917.

The present paper discusses the state-diaspora relations between India and Trinidad \& Tobago along two time periods: during indentureship and post indentureship. The first segment of the paper focuses on community life during indentureship and prior to the establishment of the Indian Mission in Trinidad 
\& Tobago. The paper contextualizes community life of 'imagined India' that the early migrants carried with them in their memories. It also deals with British policies governing the period of indentureship and the role of the Indian National Congress and Mahatma Gandhi in the abolition of indentureship in the Caribbean. The second segment of the paper focuses on the role of the Indian High Commission in promoting bilateral relations between the two nations: India and Trinidad \& Tobago. The paper attempts to provide an understanding of the strong influence the nation-state (India) has on its diasporic community in a small island state of Trinidad \& Tobago. As a result, the nationals of Trinidad \& Tobago of Indian origin have kept alive their cultural and religious traditions for over 170 years.

\section{Theoretical Framework}

The present study employs Gamlen's (2008: 842) proposition of diaspora engagement policies or 'diasporic mechanisms'. He proposes that the statediaspora relations are normal form of political organization, which has been overlooked by modern geopolitical thinkers. He further elucidates in this view that every immigrant is also an emigrant with ties to a society and state of origin. Sending states can influence these ties beyond their territorial coercive powers through mechanisms that protrude beyond their borders and operate on a transnational scale within global politics. In this context, state is defined as 'an institutional complex claiming sovereignty for itself as the supreme political authority within a defined territory for whose governance it is responsible' (Hay \& Lister 2006:5). The term 'diasporas' are conceptualized as 'dispersion to two or more locations; ongoing orientation towards a 'homeland'; and group boundary maintenance over time (Brubaker 2005; Butler 2001). A number of studies have debated on the definition of 'diaspora' and shifting paradigms and contemporary perspectives (Mitchell 1997; Clifford 1997; Cohen 1997; Gilroy 2000; Shackleton 2008; Baubock 2010; Alexander 2017) but limited space will not permit discussion those perspectives in this segment.

In his study, Gamlen uses 'state' as institutional complexes to relate to extra-territorial populations, or 'diasporas' (2008: 842). The two mechanisms employed by Gamlen are: 1) 'diaspora building' mechanisms which cultivate new diaspora communities and recognize existing ones; and 2) 'diaspora integration' mechanisms that draw resident and non-resident citizens into a 
'web of rights and obligations' as propounded by Bhagwati (2003). In the present study, I attempt to apply both diaspora building and diaspora integration mechanisms to describe cultural bonding and preservation of Indian culture and traditions prior to and after the state-diaspora relations were established between India and the Indian diaspora in Trinidad \& Tobago.

\section{Diaspora Building Mechanisms Prior to the Establishment of the Indian Mission}

As suggested by Gamlen (2008: 843), some diaspora building mechanisms cultivate diasporic identities and community structures, while others formally recognize (or reify) existing diaspora communities. He discusses two subfunction under diaspora building mechanisms: cultivating a diaspora and recognizing a diaspora.

\section{Cultivating a Diaspora}

In the absence of any diplomatic posts during the indentureship, the early Indian migrants to Trinidad \& Tobago created mechanisms of survival in the alien land. The Indian migrants to the Caribbean and to Trinidad \& Tobago in particular, were not devoid of 'inherited traditions and accumulated custom' (Parmasad 1999: 67-68). They brought their rich cultural heritage both in tangible (religious texts) and intangible forms (cultural beliefs, values) (Mahabir \& Chand 2015:2). The tangible cultural heritage the indentured laborers carried with them were wrapped up in a Jahaji bundle. The Dictionary of the English/Creole of Trinidad \& Tobago (2008: 459), defines it as 'the bundle of belongings carried by indentured laborers sailing to Trinidad from India on Jahaji' [or boat]. Samaroo (2015:129) elucidates that the indentured laborers or girmityas were allowed one piece of luggage namely a large triangular cloth called the 'Jahaji Bandal'.

In this bundle they brought the two major forms of spiritual sustenance, namely the Holy Qur'an and the Tulisdas Ramayan. In the remaining space they had a few pieces of clothing as well as the all-important seeds and cuttings which could survive the long crossings. 
These changed the landscape of the Caribbean. Mohabir (2015: para 9), alludes that, 'The jahajis and jahajins brought intangibles, such as cultural and religious practice, myths, and stories'. The intangibles were embodied in the oral traditions of the indentured laborers and were religiously passed on from one generation to the next.

The rich Indian cultural heritage of the indentured laborers was preserved and survived the oppression and exploitations of British plantation owners, harsh living conditions in the barracks, and the ridicules of their African neighbors for over 170 years (Murali 2015:9)

\section{Formation of Mini India in Trinidad}

The Indian indentured laborers who arrived in TRINIDAD \& TOBAGO were from various religious groups, castes, economic class and geographical regions in India. About $85 \%$ of the indentured laborers, particularly to Guyana $(238,909)$ and Trinidad \& Tobago $(147,592)$, were Hindus, $15 \%$ were Muslims and 0.1\% were Christians (Vertovec 2000:44, Jain 1993: 23). Among Hindus, the various castes included Brahmanas, Kshatriyas, Bhumihars, Rajputs and Thakurs, as well as farmers, Ahirs [cowherders], artisans, fishermen and boatmen. Low-caste migrants were Chamaras and Sudras who came mainly from South India (Mohanty 2014: 86, Clarke 2013: 20, Naidu 2007, Jayaram 2006). About $90 \%$ of the indentured laborers came from the states of Bihar, Oudh, Orissa, United Providences [Uttar Pradesh \& Uttarakhand today], Central Provinces and Bengal, small proportions were from Punjab, Himachal Pradesh, Kashmir, Kerala, Andhra Pradesh, Rajasthan, and Maharashtra (Wood 1968; Brereton 1985:21; Edmonds \& Gonzalez 2010:178). There were persons from the tribal areas in Bihar and Bengal, known as 'hill coolies' (Jha 1985: 1). Emigrants were also from Nepal and Afghanistan (Edmonds \& Gonzalez, 2010). According to Edmonds \& Gonzalez (2010:178), 'a miniature of India and also of Sub-Continent was re-created in Trinidad'.

\section{Kinship and Bonding}

The earliest bonding among the Indian laborers took place aboard on the first ship, Fatel Rozack to the shores of Trinidad. To survive the treacherous journey over the seas [referred to as kala pani or dark waters], to the unknown foreign land, laborers from all strata [caste, religion, class and ethnicity] found solace 


\section{Susan Julia Chand}

in each other's company and established brotherly bonds that came to be known as Jahaji bhai [Ship brotherhood] (Mohanty 2014: 61-62; Dabydeen \& Samaroo; 1987). The bond of brotherhood extended further as the laborers, both men and women toiled together in sugar plantations under the British colonizers (Mohanty 2014: 62; Vertovec 2000). Indentured laborers began to form new kinship networks even before they arrived in Trinidad. Close relationships formed on shipboards were maintained for years, even generations, to the extent that in practice the indentured laborers would not allow their children to marry each other. They helped each other to find spouses for their children in separate villages as their relatives did in India (Encyclopedia of World Cultures 1996).

\section{Social Life and Religious Festivals}

As indentured labourers settled in the communities, they recalled how their evenings were spent in their native villages in India. They journeyed down memory lane to recall the festivals they had celebrated. Having no access to a Hindu or Islamic calendar, they observed the seasons and celebrated the major Hindu festivals like Phagwa [Festival of Colours] and Divali [Festival of Lights], Eid and Hosay.

Socio-cultural life of Hindus: Since early 1860s, Hindus in Trinidad have been celebrating religious festivals such as Divali, Navratri, Phagwa, Shiv-ratri, Kartik, and Ganga Dhaara (Edmonds \& Gonzalez 2010: 179; Mahabir \& Chand 2015: 3). The times and seasons for the festivals were observed in nature. For example the blossoming of the poui trees [Tabebuia serratifolia ] were seen as the beginning of Phagwa, which corresponded with spring in India (March - April) (Mahabir \& Chand 2016: 5). Similarly, the time and season for Dusshera [burning of the demi god by the Hindu god Rama] and Divali were determined. According to Jagessar Ganesh (2007),

going to the bamboo patch and doing prayers and such things before we cut was an important memory of his childhood. Because the bamboo cannot be cut during Pitri Paksh (the memorial period of remembrance of the departed souls), which comes before Dussehra, and thus it has to be cut some three or four weeks before Ramleela (Riggio 2010: 127). 
Divali was therefore celebrated 14 days after Dussehra, according to the account given in Ramayana. An outstanding phenomenon emerging in the community was the staging of open-air theatre Ramlila depicting the story of Rama which culminated in Dussehra. The earliest documented record of Ramlila in Trinidad can be traced back to 1880 in Dow Village, California, and has an unbroken history of over 135 years of performance (Riggio 2010: 126).

Amidst the difficult working conditions, Indians sought comfort in their religious and cultural practices. Workers came together during the evenings and weekends at organized activities like wrestling matches, stick fighting, playing of traditional games (kabaddi, guli danda, luha/lohar, eka buka), singing of bhajans [devotional hymns], alhas [narratives] and reading from the Ramayana and Mahabharata (Mohanty 2014:72, Edmonds and Gonzalez: 2010: 179-180, Mahabir: 2007) which some migrants would have brought along. Plantation owners allowed Hindus to practice their religion on the sugar estates (Naidu 2007).

Firepass, a South Indian ritual that included walking over hot coals [was banned 20 years later by the Government].

Socio-cultural life of the Muslims: Hosay, a street festival commemorating the martyrdom of Husyn (grandson of Mohammed) were celebrated by the Indian Muslims. Even though Hosay was a Muslim festival, it became a major Indian religious festival in Trinidad.

\section{Subsistence and Commercial Activities}

According to Samaroo (2015: 130), when the Indians completed their indentured labor, thousands reverted to their original occupations [weaving, pottery, herding, barbers, iron and gold smiths, and the like] thus adding to the skills-base of their colonies.

However, most of the East Indians after the indentureship, in the rural areas continued to work on sugar estates; some found work in cocoa estates while others supported themselves through fishing and 'crab-catching', particularly those living close to the Caroni Swamp. By 1873, East Indians were cultivating wet rice and paddy fields were prominent from Caroni Swamp to the edges of Oropouche Lagoon providing one-sixth of the local consumption (Brereton 1985: 27-28; Wood 1968: 276; Niehoff \& Niehoff 1960: 31). Most East Indians were familiar with growing wet rice as it was one of the staple crops in India. Other crops grown were all kinds of provisions, 


\section{Susan Julia Chand}

varieties of peas and beans and green vegetables. The East Indians' love for agriculture gave rise to a vibrant peasant class, an important contribution to the economic life of TRINIDAD \& TOBAGO. They were granted 5-10 acres of Crown lands between 1869 and 1880 in lieu of free passage to India (Brereton 1985: 27- 28; Vertovec 1992: 20). They soon formed their own villages, building houses, engaging in agriculture, and re-creating the same environment as they had in India.

By early 1900s, the East Indians became one of the largest land owning classes in the country. Thus, encouraged by their ownership of 'a piece of Trinidad' they began the task of building a society in their new land (Gooptar 2015: 213).

\section{Educational Endeavours}

East Indians regarded education as highly desirable. However, their children were not admitted to schools run by the Christians unless they were converted to Christianity. Hindus and Muslims were not granted permission to run their own schools. A vast majority of the children of the indentured laborers stayed home or worked in the plantations. Canadian Missionaries intervened and provided education through Presbyterian schools to the children of East Indian descent and thereby played a critical role in uplifting the social status of the East Indians (Brereton 1985: 28-29; Doodnath 1983: 40-41) in a Africandominated society. Those who became doctors, lawyers, and school teachers were held in great respect. Dr. John Morton was the first Canadian Missionary to propose to the then Governor Hamilton Gordon a scheme with special privileges for Indian education. The first Canadian Missionary School (today known as Presbyterian schools) was opened in March 29, 1868 with 14 Indian children in Iere village (Doodnath 1983: 41).

It was in 1950s that Hindu sponsored schools were opened through the efforts of Badase Sagan Maharaj who became the founder of Sanatan Dharma Maha Sabha (SDMS). Extended visits during this period by Indian missionaries (known as the 'Swamis') resulted in an increased interest in Hinduism on the part of many young men; at the same time, the new schools built by the Maha Sabha introduced the teaching of Hindi and Sanskrit along with customary Western secular subjects (Encyclopedia of World Cultures 1996; Campbell 1985: 119). 
Similarly, the Muslim community established 'maktabs' [elementary schools] and 'madrasas' [centers of learning whether school, college or university established for teaching of Islam] where moulvis [Islamic scholar] and imams [worship leader of a mosque of a Muslim community] imparted learning in Urdu and Arabic. The Village Mosque as a centre of community activity dates back to 1860 s.

Through these channels of education, elements of Indian culture were kept alive.

\section{Marriage}

Until 1946 marriages performed by Hindu priests were not legally recognized neither Muslim marriages before 1930s, by the Trinidad \& Tobago law (Jha 1985:2). They were not registered with the District Registrar and therefore their children were considered as illegitimate in the eyes of the law. For Indians, the religious ceremony was considered more legitimate than the civil registration of marriage (Brereton 1985: 20).

\section{Co-existence of Religious Groups}

Religion has always been central to Indian life. As D.N. Vidyarthi put it (from '130 Years - Challenge and Transition'),

Whatever else our ancestors might have left behind them as they embarked on their great adventure, they did not neglect to transplant their religious customs and traditions. The crucible of immigration, however, was happily responsible for the removal of much that elsewhere made for the unnatural stratification of community life (Kirpalani et al:: 1945: para 1).

Since the earlier days of indentureship and thereafter, East Indians of varied religious, cultural and regional groups co-existed harmoniously. In the 1930s, just fifteen years short of the 100th anniversary of the commencement of Indian indentureship, L.F. Seukaran, politician and later elder statesman, remarked:

Here, fortunately for us, Hindu, Muslim and Christian Indians enjoy unfettered social intercourse. There is much tolerance of one another's 


\section{Susan Julia Chand}

religious viewpoint and practices, and even among the various religious groupings, sectarian differences do not seem to cut deeply into social relationships (Kirpalani et al.: 1945: para 2).

In 1931, the Indian population stood at 138,667 , made up of Hindus $(94,125)$, Christians (23,183), Mohammedans (20,747), Buddhist (119), Parsi (278) and others (215) (ibid: para 3).

\section{Media}

The first Indian movie that came to Trinidad was Bala Joban in 1935. Though rated as an average in India, this movie attracted East Indians from every corner to watch the first Indian motion picture in Trinidad. For the first time they felt connected to their motherland, India after being cut off for 90 years. According to Gooptar (2015: 219),

To a people who were starved of things Indians who pined for India, who had created an imagined India and sought to re-create among themselves the India that they had left behind, the coming of this new Indian spectacle in 1935 was like 'India coming to them in Trinidad' or 'a slice of India' greeting them.

They were ecstatic about the clothing, jewelry, kitchen utensils, musical instruments and Hindi language depicted in the movie as those were similar to their own that were preserved and inherited from their fore-parents. As Indian movies continued to arrive in Trinidad, the East Indians drew parallels between their local cultural frames and those seen in the movies, particularly the portrayal of arranged marriages, the Panchayat system, gender and caste/class issues, patriotism, and the like. Through the Indian movies, the East Indians reinforced their cultural identities and value systems and kept alive the 'imagined India' in their memories. Beginning in 1938 and through 1940s, Indian movie-inspired singing competitions, orchestra bands, dance groups and new genre of music (Chutney) emerged in the island.

In sum, the local East Indians linked culture they saw in the Indian movies to their traditional local cultural and religious experiences in 
the settlement and created new identity markers (Gooptar 2015: 226$7)$.

\section{Rise of Political Leaders}

Prior to and following the abolition of indentureship, there was a rise in social activists and political leaders. According to Cudjoe (2010), by the 1890s, the East Indians moved from the estates to the newly established villages and began forming a political force in the island. In 1897, the East Indian National Association of Trinidad was formed and later became one of the major Indian political organizations during the early twentieth century defending the interests of the East Indians in TRINIDAD \& TOBAGO. During this period, the East Indians participated in mayoral politics in San Fernando and in the movement for constitutional change. They reconstructed the panchayat, one of the traditional Indian social institutions for challenging political activities in the country.

In 1925, the first elective legislature was established in Trinidad \& Tobago. Although the East Indians were against the elected system their fears turned out to be ill-founded. At the first election one Indian member, Sarran Teelucksingh was selected. In 1928, Teelucksingh was joined by two other Indian members, F. E.M. Hosein (St. George) and T. Roodal (St. Patrick). Roodal, a leading member of Cipriani's Workingmen's Association, brought a substantial section of the Indian working class into the labor movement with him. Eventually, Roodal emerged as an important leader in the Indian community. Adrian Reinzi, a fourth Indian was elected to the Legislative Council in 1938. An important leader in the society, Reinzi worked with Tubal Uriah 'Buzz' Bulter and the labor movement to advance the causes of both the East Indian and labour (Cudjoe 2010; Encyclopedia of World Cultures 1996; Samaroo 1985: 83-86).

In summary, according to Gamlen (2008), maintaining national culture abroad is one way of cultivating diasporic identity. In case of the Indian indentured labourers in Trinidad \& Tobago, national culture was expressed through their social, cultural, religious, educational, and political organizations that were derived from the values they had internalized in their homeland and re-constructed in the foreign land. 


\section{Recognizing the Diaspora Prior to the Establishment of Indian Mission in Trinidad \& Tobago}

According to Gamlen (2008: 844), states have various mechanisms for recognizing (reifying) diaspora communities. Formally recognizing diaspora communities involves dedicated bureaucratic structures. However, in the absence of Indian diplomatic post in Trinidad \& Tobago, most of the time British policies governed the indentured labourers.

\section{British Policies and East Indians}

Evidently, the East Indians adhering to their cultural values and practices engendered resentment from the Africans and the plantation owners. In the environment of mid- $19^{\text {th }}$ century, where adoption of European culture and Christian ethic were norms, the East Indians holding on to their language, dress, religion and their profound philosophical attachment to the motherland (Dharti Mata) were viewed as 'adverse influence which has to be met and dealt with' (Samaroo 1985: 80). The physical and cultural differences were so visible that accentuated the isolation of the East Indians from the rest of the society. Jha (1976) and Samaroo (1979) observed that the hostility from the wider society forced the East Indians to form their own kindred organizations to look after their own interests. They also arranged regular visits by Indian missionaries and scholars, imported Indian films from the thirties that generally identified with problems in the sub-continent (as cited in Samaroo 1985: 80).

The Official British policy, on the other hand, contributed much to the confusion about the role of the East Indians whether to adopt a 'pluralist' or a 'consensualist' approach to the group in question. Officially, the colonial government conveyed clearly that their policy was a consensualist one and that East Indians were not separate but part and parcel of the larger West Indian society. They should therefore be given no encouragement to operate separately or to look to India for the alleviation of their problem (Samaroo 1985: 80). In 1938, the Colonial Office advisers demonstrated their stand for a consensualist approach by strongly opposing the demand by the Government of India (G.O.I) that a British Indian Civil servant be sent with the Moyne Commission to safeguard the interests of the East Indians in the Caribbean. Again, in 1941, The Colonial Office advised that both the India Office in 
London and the Government of India in Delhi should be discouraged from the view that they had to be consulted before the institution of measures which would affect Caribbean East Indians. The Indian Officials were to encourage East Indian populations to consider as part of the general population and not as off-shoots of India (Rogers 1941; cited in Samroo 1985: 82). This directive was put forth to deal with situations where the East Indians were requesting for intervention from the government to resolve issues relating to Hindu and Muslim marriage laws and financial assistance to Hindus or Muslims who wished to open their own schools.

\section{Towards Abolition of Indian Indentureship in Trinidad \& Tobago}

In January 1920, the system of bonded labor or indentured labor in all the British colonies was abolished following series of agitation led by Mahatma Gandhi in South Africa from 1885 onwards. In an article published in the local newspaper, the Guardian, commemorating 100 years of abolition of indentured labor in TRINIDAD \& TOBAGO, author Mahase (2017: 4) notes:

the decision to stop the shipping of labourers to Trinidad came from outside of the island. The Trinidad planters had little or no involvement in the entire abolition process. This was actually the result of massive protests against the labour scheme which started in the late 1800s by Mohandas Karamchand Gandhi in Natal.

The move towards abolition of Indian Indentureship was a long drawn historical process that underwent numerous obstacles put forth by both arms of the government, the British Imperial Government and the Government of India. One of the key players in facilitating the process was the Indian National Congress (I.N.C.) founded in 1885 as a reaction to the repressive and exploitative policies of the British colonial states. It was an organized expression of Indian nationalism in the country.

The hardships, exploitation and abuse of indentured labourers in Trinidad \& Tobago under the British regime drew the attention of the Government of India through the agitation led by Mahatma Gandhi and initiative taken by the INC. The human rights of the Indian diaspora in Trinidad 
$\&$ Tobago and world-wide were accorded recognition and liberation from indentureship.

\section{Diaspora Building and Diaspora Integration during Post-Indentureship in Trinidad \& Tobago}

Historically, India and Trinidad \& Tobago have been in contact for over 170 years although formal diplomatic relations were established in 1962. Both countries share certain common features that they could identify with: both were colonized by the British; both nations gained independence from British rule; both possess diverse natural and large economic resources; both are members of the Commonwealth of Nations, G-77 and the Non-Aligned Movement (NAM); and lastly, they are ethnically heterogeneous in composition. Although, Indian diaspora in TRINIDAD \& TOBAGO is considered as a single largest ethnic group in the country, in reality there exists multi-ethnic groups within the diaspora mostly based on religious affiliations (Hindus, Muslims or Christians). Also included in the diaspora are the recent migrants and Non-residents of India (NRIs). There are about 600 families (1800 people) of NRIwho are engaged in medicine, academia, business, law and other professions (Diplomat Special Report: 2014: 8, High Commission of India 2017) for over the last 30 years or more.

\section{Diaspora Building}

\section{Cultivating a Diaspora: Promoting Cultural Ties and}

\section{Educational Opportunities}

The Indian High Commission in Trinidad \& Tobago has been instrumental in cultivating cultural ties and opening educational opportunities through a number of initiatives and signing of bilateral agreements in the areas of cultural cooperation, cultural exchange programmes, science and technology, technical cooperation, agricultural research and education during the period 1985 to 2015.

The Mission has been engaged in active cultural diplomacy through its Cultural Wing, Mahatma Gandhi Institute of Cultural Cooperation (MGICC), established in 1997 under a Bilateral Cultural Exchange Programme. It promotes art and culture both at the Government and Non-Governmental levels 
through cultural and teaching activities in Indian classical music and dance. Currently, the Institute has 3 Indian-based teachers in vocal music, table and Bharatanatyam dance and one local Yoga teacher who conducts classes over the weekends. Furthermore, the Institute collaborates with several sociocultural and educational institutions in teaching of music and dance, thereby providing greater awareness of India's composite cultural heritage. It conducts the monthly 'Kala Sandhya' lectures and workhops and also offers annual scholarships under Indian Council for Cultural Relations (ICCR)'s General Cultural Scholarship Scheme.

Another notable area has been the collaboration with the ICCR, chairs for Hindi and Contemporary Indian Studies with the regional university, University of West Indies (UWI) in 2012 for the period of 3-5 years. Two professors from India were deputed in these departments in UWI. During their tenure of service, they organized a series of seminars, workshops and conferences in which the academicians from local universities participated and presented papers on related disciplines. World Hindi Conference, International Hindi Conference and Hindi Kavi Samellan were conducted under the area of Hindi.

Ayurveda and Traditional Indian Medicines is another area that the Indian High Commission has been widely promoting. Even though MoUs have been signed in 2012 between Central Council for Research in Ayurvedic Sciences and UWI with setting up of a chair, and opening of a center for information on Ayurveda, no report on any research on Ayurvedic Sciences or activities of the department have been published in the public domain so far. However, a number of scholarships are advertised through the Indian High Commission's website inviting on an annual basis, students interested to pursue undergraduate/post graduate/PhD programmes in Ayurveda, Yoga, Unnani, Sidda and Homeopathy (AYUSH), Scholarship programme for Diaspora children (People of Indian Origin and Non-resident Indians) to pursue undergraduate courses in Indian Universities or Institutes (except in Medical and related courses) both professional and non-professional courses (High Commission of India 2017).

The Government of India (GOI) offers scholarships and assistance to TRINIDAD \& TOBAGO under the Indian Technical and Economic Cooperation (ITEC) Programme, ICCR scholarships, Know India Programme (IP), and deputation of experts from India. The ITEC programme focuses on capacity building and human resource development in 161 developing nations 
around the world since 1964. In TRINIDAD \& TOBAGO, 40 slots are offered every year for scholars to be trained under this programme. During the last 7 years, about 143 scholars have been trained in India under this programme (Special Report India and Trinidad \& Tobago2014: 9). This is about 51\% of the total slots offered each year, that means about $49 \%$ of the slots are not utilized. According to Badri-Maharaj (2017), the relative lack of success of the ITEC. Scholarship Program in the L.C region may be attributed to diplomatic shortcomings. Started in 1964, this program offers over 8000 scholarships globally. Unlike Africa and Asia, India's ITEC slots allocated to the region are significantly underutilized. For example out of 638 slots allocated to the region in 2013-2014, only 393 were utilized. This has been true of the situation in TRINIDAD \& TOBAGO.

On the other hand, during the past 10 years, 16 participants under the ICCR scholarship programmes and 112 young members of the Indian Diaspora under the KIP programme have visited India till date. One can find detailed information on the scholarship programmes under ICCR.at the High Commission's website which are advertised for every academic year. However, these have not attracted significant number of scholars to apply and make use of the opportunity to study in India. The scholarships advertised are the General Scholarship Scheme inviting students of Trinidad \& Tobago for undergraduate, postgraduate degrees and doctoral research in a wide range of disciplines,

TRINIDAD \& TOBAGO have over 201 secondary schools, 3 prominent universities and over 10 recognized and accredited tertiary institutions with close to $60 \%$ of the country's 1.3 million population (census) as the student population (Trinidad \& Tobago 2011 Population and Housing Census Demographic Report: 2012: 18). Hence, with robust marketing strategies, candidates for ICCR scholarships can be increased from the wealth of student population provided by TRINIDAD \& TOBAGO.

\section{Humanitarian Services, Conferences and Publications}

The Indian High Commission has been engaged in community work through health camps, Health rallies and promotion of World Yoga Day as well as render support to organizations like Sisters of Charity in TRINIDAD \& TOBAGO. As one browses through the High Commission's website and Facebook, a number of events have been listed and displayed in the photo 
gallery. Noteworthy has been the hosting of conferences on 'Modern time and Ancient wisdom' (2014), and 'The Relevance of Swami Vivekananda' (2015), co-hosting conferences on 'Indian Diaspora in the Caribbean' in TRINIDAD $\&$ TOBAGO $(2010,2015,2017)$ and Grenada (2016), hosting Diwali celebrations at the National Council of Indian Culture center, Hindi Day celebrations, ITEC day, Gandhi Jayanti, India's Independence and Republic Day celebrations, Annual convocation ceremony of MG.CC and hosting numerous cultural programmes across the country.

The Indian High Commission has to its credit a number of publications both in print as well as digital and online. Some of the latest publications have been 'Extraordinary and Plenipotentiary Diplomatist: Special Report' (2014 \& 2016) and 'India in the Caribbean: Socio-Cultural Moorings of Diaspora' (2015) initiated and coordinated by the former High Commissioner, Gauri Shankar Gupta. The High Commission has an in-house Library open to the public with a wide variety of collections ranging from cultural biographies to newspapers and magazines, documentary and feature films.

\section{Recognizing the Diaspora \\ Diplomatic Visits}

There have been a number of diplomatic visits by the high ranking officials of India and TRINIDAD \& TOBAGO. Prime Minister Indira Gandhi in 1968 was the first Prime Minister to visit at the invitation of the Government of TRINIDAD \& TOBAGO. A cultural pageant was organized at her reception at Port of Spain. A large number of people of Indian origin (PIOs) had gathered to affirm their kinship bond with India. Industrial potential and diversification of economy were discussed between the two leaders and TRINIDAD \& TOBAGO was offered technical assistance under ITEC programme (MEA Report 1968-69: 1967:49). After a gap of 30 years, visits were made by the former Prime Minister Atal Bihari Vijpayee (1999) and Prime Minister Manmohan Singh who led a high level delegation for the Common Wealth Heads of Government Meeting (CHOGM) Summit in November 2009. From TRINIDAD \& TOBAGO, the Prime Minister Basdeo Panday was invited as a Chief Guest on the occasion of India's Republic Day (1997) and Prime Minister Kamla Persad Bissessar (2012) paid a State visit to India. During the visit a number of agreements and MOUs were signed in the areas of Bilateral Air Services agreement, Technical Cooperation Agreement on Education, 


\section{Susan Julia Chand}

Cultural Exchanges and cooperation in the field of Traditional Medicine (Special Report India and Trinidad \& Tobago 2014: 9, High Commission of India 2017). Both the former Prime Ministers' visits were seen as leaning more towards cultural and kinship ties in connecting to one's ancestral roots.

\section{Participation in Joint Commission Meeting (JCM)}

The first meeting of the India-TRINIDAD \& TOBAGO Joint Commission Meeting was held in New Delhi in November 2011. Areas of discussion included Science \& Technology, air transport, agriculture, SMEs, education, healthcare, tech. co-operation, energy and trade. There has not been another one since then.

\section{Participation in Pravasi Bharatiya Divas $(P B D)$}

Pravasi Bharatiya Divas is organized to mark the expatriates' contribution in the development of India. PBD is held every year on January 9 (since 2003) commemorating Mahatma Gandhi's return to India from South Africa, in 1915. These conventions provide a platform to the overseas Indian community to engage with the government and people of India for mutually beneficial activities, discuss key issues concerning Indian Diaspora, and network among the overseas Indian community residing in various parts of the world (Ministry of External Affairs: 2017). During the event, individuals of exceptional merit are honoured with the prestigious Pravasi Bharatiya Samman Award (PBSA) to appreciate their role in India's growth. The recipients of PBSA have been the Former Prime Minister of Basdeo Panday (2005), National Council of Indian Culture (NCIC) (2008), former Prime Minister Kamal Persad Bissessar (2012) and the former Minister of Foreign Affairs, Dr. Winston Dookeran (2017) (High Commission of India 2017).

\section{Economic and Commercial Relations}

It is true that TRINIDAD \& TOBAGO is one of the 'gateway' countries (others being Guyana and Suriname) in the Caribbean that India could with the right policies, some innovation and diplomatic initiative use as springboard for greater involvement in the region, particularly in the Latin America. Along this line, Badri-Maharaj (2017 noted that one of the major success stories of the 
last decade has been the significant increase in trade ties between India and the Latin America- Caribbean (LAC) region. To illustrate his point he cited Rengaraj Viswanathan, former Ambassador and expert in Latin American politics, market and culture, as stating that

India's trade with Venezuela ( $\$ 12.24$ billion) and Brazil ( $\$ 11.36$ billion) in 2014-15 was more than its trade with Sri Lanka (\$7.4 billion), Bangladesh ( $\$ 7$ billion), Thailand ( $\$ 9.3$ billion) and Vietnam ( $\$ 9.2$ billion) as well as with traditional partners France ( $\$ 9.4$ billion) and the Netherlands ( $\$ 8.7$ billion).

Viswanathan (2005: 114), also noted that the Indian pharma companies have successfully been established as well as achievements in information technology in these countries have enhanced the image of India. Thus,

there are more opportunities for medium and small countries and companies of LAC region to provide greater opportunities for India since Chinese companies go for large markets and volumes.

TRINIDAD \& TOBAGO provides good opportunities to exporters from India to access the Caribbean region and beyond. There is potential for growth of bilateral trades in textiles, garments, pharmaceuticals, energy, machinery and petro-chemicals, agriculture, Information Technology and Film \& Music Industry (High Commission of India 2017).

\section{Indian Arrival Day Celebrations}

One of the event celebrated extra-territorially is the Indian Arrival Day by the people of Indian origin in different parts of the Caribbean on different days. In Trinidad \& Tobago, May 30 is proclaimed as the Indian Arrival day and a national holiday since 1994. The day is commemorated with prayers, speeches, songs, music, dances and plays in communal and public places. The reenactment of the landing of the first boat-load of Indian migrants are displayed at various beaches. The citizens are encouraged to display old photographs and artifacts relevant to the history of the Indians in the Caribbean (Mahabir 2017). This annual event exhibit sentiments of the young generations 
as they pay their homage to their forefathers. It is also a time to reflect on their connectedness with their homeland.

\section{Diaspora Integration}

According to Gamlen (2008: 844), diaspora integration examines the rights that the origin states extend to diasporas and the obligations they attempt to extract from them. Gamlen propounds that the mixture of generosity and appeals to patriotism that states make towards diasporas are not simply a strategy in a game between separate players, but rather a form of sovereignty claim of state over citizen-one that operates through consent rather than coercion.

The present paper discusses the above diaspora mechanism under four areas: establishment of forums (we-feeling), consular services, avoidance of double taxation, and emergency and relief services provided by the Mission.

\section{Establishment of Forums under Auspices of the Mission}

Forums established by the Mission bring the Indian nationals and family members living in TRINIDAD \& TOBAGO together for humanitarian service and social events. The Forum of Indian Nationals in TRINIDAD \& TOBAGO (FINTT) is one of such forum that was launched on 17 September 2011. The Know India Youth-Trinidad \& Tobago (KIYTT) is another forum formed in October 2011 particularly to interact with the participants in the Know India Programme (KIP) in TRINIDAD \& TOBAGO. KIYTT carries out activities such as organizing cultural programmes, talk shows on TV channels, highlighting developments in different sectors in India and community activities. Indian Alumni Association of Trinidad \&Tobago (IAATT) constitutes of scholars and other professions who have either studied or trained in India. Currently, there are no updates on the activities of the above mentioned forums in the public domain.

KIYTT has been actively promoting various schemes of the Government of India meant for them such as the OCI scheme, Know India Programme (KIP), Tracing the Roots Programme, Scholarship Programme for Diaspora Children (SPDC) and Pravasi Bharatiya Samman Award. The Mission Provides regular and prompt consular services to the Non-resident 
Indian community residing in TRINIDAD \& TOBAGO and other concurrently accredited countries (High Commission of India 2017).

\section{Avoidance of Double Taxation}

India and Trinidad \& Tobago have signed a treaty on avoidance of double taxation for the NRIs working in TRINIDAD \& TOBAGO since 1999.

\section{Consular Services}

The Government of Trinidad \& Tobago has waived visa requirements for Indian nationals visiting TRINIDAD \& TOBAGO for tourism and business purposes for a period of three months. The Government of India has approved e-Tourist Visa for TRINIDAD \& TOBAGO citizens. Furthermore, the High Commission's website has all relevant updated information for the application of PIO cards and the application for Overseas Citizens of India (OCI) cards. Currently, all PIO cards are being replaced by OCI cards (High Commission of India 2017).

\section{Emergency and Relief Operations}

The Indian High Commission is committed to provide relief services to the Indian nationals in case of emergency or natural disasters. A recent example is seen where the Mission evacuated nine Indian nationals from Dominica where hurricane devastated the country.

\section{Final Analysis}

The paper began by examining Gamlen's (2008: 841) proposition of diaspora engagement policies or diaspora mechanisms, namely diaspora building and diaspora integration during and post Indian indentureship in Trinidad \& Tobago. Additionally, the paper described the state-diaspora relations between India and the Indian diaspora in Trinidad \& Tobago during the same period of time. Gamlen posited that contrary to the popular notions on state-diaspora relations as abnormal (Anderson 1992; Agnew 2003; Van Hear, Pieke \& 
Vertovec 2004; Schiller 2005; De Haas 2006 as cited in Gamlen 2008: 841), it is normal for states to have a variety of diaspora mechanisms be it diaspora building or diaspora integration, to protrude their borders and impact on a variety of extra-territorial groups.

Gamlen (2008: 852) proposed a model to gauge the engagement or disengagement between the state - diaspora relations. His model demonstrates a typology of emigration states (see Figure 1.1. According to his model, a state may have diaspora building mechanisms which include attempts to coordinate policies with a diaspora dimension; or diaspora integration mechanism which include many state policies with diaspora dimensions. However, there rarely is a situation where both or neither diaspora mechanisms exist. When both mechanisms exist, then the state-diaspora are said to be engaged whereas, when both the mechanisms are absent, a state of disengagement exists. In a situation where one of the mechanisms is present, the condition is either 'paper only' or 'incoherent'. When applied to the state-diaspora relations between Indians and Trinidad \& Tobago, it can be seen that a number of policies have been directed by the state to promote diaspora building mechanisms through cultural, religious and educational programmes aimed at both Indo-Trinidadians and NRIs. Diaspora integration mechanisms are limited to consular services to citizens of TRINIDAD \& TOBAGO and NRIs and relief operations exclusively to NRIs. However, we cannot draw conclusions on the engagement or disengagement situation between state-diaspora relations in the context of India-TRINIDAD \& TOBAGO relations based merely on the description attempted in this paper. This study was exploratory in nature and more in-depth analysis of Gamlen's model/proposition should be conducted to arrive as what he perceived as 'emigration states'.

\begin{tabular}{|l|l|c|c|}
\hline & \multirow{2}{*}{\begin{tabular}{c}
$|c|$ \\
\cline { 3 - 4 }
\end{tabular}} & \multicolumn{2}{c|}{$\begin{array}{c}\text { Diaspora Building Mechanisms } \\
\text { (Diasporic identities) }\end{array}$} \\
\cline { 3 - 4 } \begin{tabular}{l} 
Diaspora Integration \\
\cline { 3 - 4 } $\begin{array}{l}\text { Mechanisms (Rights } \\
\text { and Obligations) }\end{array}$
\end{tabular} & Yes & Engaged & Incoherent \\
\cline { 2 - 4 } & No & Paper Only & Disengaged \\
\hline
\end{tabular}

Figure 1.1: Typology of Emigration states (Gamlen 2008: 852). 


\section{Conclusion}

East Indians in TRINIDAD \& TOBAGO are proud of their rich cultural heritage and of their ancestral homeland, India. Almost all of India's efforts have been focused on cultural activities, in which the Indian diplomatic mission has had good success. The Indian Mission in TRINIDAD \& TOBAGO should advertise scholarship opportunities to all citizens of TRINIDAD \& TOBAGO and not only limit to Indo-Trinidadians to increase remittances from this nation through educational opportunities of studying abroad and internship programmes. India as a nation-state should also engage in more favorable diaspora integration policies for Indian nationals in TRINIDAD \& TOBAGO such as providing opportunities to participate in electoral processes remotely. However, it is time that India should no longer be in muted relations with Trinidad \& Tobago. India should consider pooling the Caribbean countries like Trinidad \& Tobago, Guyana and Suriname with the largest concentration of people of Indian origin and be more pro-active in economic investments, particularly in the areas of agriculture and natural resources that these countries are known for.

\section{References}

Agnew, J. 2003. Geopolitics: Revisioning World Politics. London: Routledge. Alexander, C. 2017. Beyond the 'The Diaspora 'diaspora': A Response to Rogers Brubaker. Ethnic and Racial Studies 40,9: 1544 - 1555.

Anderson, B. 1992. The New World Order. New Left Review May/June I:193: $7-16$.

Badri-Maharaj, S. 2017. Why Trinidad, Guyana and Suriname should Matter

to India? Swarajya. Available at: https://swarajyamag.com/world/whytrinidad-guyana-and-suriname-should-matter-to-india. (Accessed on 20 October 2017).

Baubock, R. \& T. Faist 2010. Diaspora and Transnationalism: Concepts,

Theories and Methods. Amsterdam: Amsterdam University Press.

Bhagwati, J. 2003. Borders beyond Control. Foreign Affairs 82,1: 98 - 104.

Brereton, B. 1985. The Experience of Indentureship. In La Guerre, J. (ed.):

From Calcutta to Caroni. Trinidad \& Tobago: University of the West Indies. 
Brubaker, R. 2005. The 'diaspora' Diaspora. Ethnic and Racial Studies 28,1: $1-19$.

Butler, K.D. 2001. Defining Diaspora, Refining a Discourse. Diaspora 10,2: 189 - 219.

Campbell, C. 1985. The East Indian Revolt against Missionary Education, 1928 - 1939. In La Guerre, J. (ed.): From Calcutta to Caroni. Trinidad \& Tobago: University of the West Indies.

Central Statistical Office 2011. Trinidad \& Tobago 2011 Population and Housing Census: Demographic Report 2011. The Republic of Trinidad \& Tobago: Ministry of Planning and Sustainable Development. Central Statistical Office.

Clarke, C. 2013. Religion and Ethnicity as Differentiating Factors in the Social Structure of the Caribbean. MMG Working Paper. Göttingen: Max

Planck Institute for the Study of Religious and Ethnic Diversity.

Clifford, J. 1997. Routes: Travel and Translations in the Late Twentieth

Century. London: Harvard University Press.

Conen, R. 1997. Global Diasporas. London: ULC Press.

Cudjoe, S.R. 2010. The Changing Social and Political Landscape of Trinidad \& Tobago. A Lecture delivered at the Trinidad \& Tobago Bureau of Standards.

Dabydeen, D. \& B. Samaroo 1987. India in the Caribbean. Warwick, UK: Centre for Caribbean Studies Publications.

Doodnath, S. 1983. Short History of the Early Presbyterian Church and the Indian Immigration 1845 - 1945. Port of Spain: n. p.

Edmonds, E.B. \& M.A. Gonzalez 2010. Caribbean Religious History: An Introduction. New York: NYU Press.

Encyclopaedia of World Cultures 1996. East Indians in Trinidad. Available at: http://www.encyclopedia.com/humanities/encyclopedias-almanacstranscripts-and-maps/east-indians-trinidad. (Accessed on 11 October 2017.)

Gamlen, A. 2008. The Emigration State and the Modern Geopolitical Imagination. Political Geography 27: 840-856.

Gilroy, P. 2000. Between Camps. London: Allen Lane.

Gooptar, P. 2015. Memory, Indian Films and the Creation of Indian Identity in

Trinidad. In Murali, A. (ed): India in the Caribbean: Socio-Cultural Moorings of Diaspora. New Delhi: India Empire Publications.

Hay, C. \& M. Lister 2006. Introduction: Theories of State. In Hay, C., M. Lister 
\& D. Marsh (eds.): The State: Theories \& Issues. New York: Palgrave McMillan.

Heine, J. \& H. Seshasayee 2016. Recasting South-South Links: Indo-Latin American Relations. In Roett, R. \& G. Paz (eds.): Latin America and the Asian Giants: Evolving Ties with China and India. Washington, DC: The Brookings Institute.

High Commission of India 2014. Extraordinary and Plenipotentiary Diplomatist: Special Report. Port of Spain: L.B. Associates Pvt Ltd.

High Commission of India 2017. Trinidad \& Tobago Relations. Available at: http://www.hcipos.in/eoi.php?id=Trinidad. (Assessed on 8 October 2017).

Jain, R.K. 1993. Indian Communities Abroad: Themes and Literature. New Delhi: Manohar Publishers and Distributors.

Jayaram, N. 2006. The Metamorphosis of Caste among Trinidad Hindus. Contributions to Indian Sociology 40, 2: 143-173.

Jha, J.C. 1985. The Indian Heritage to India. In La Guerre, J. (ed.): From Calcutta to Caroni. Trinidad \& Tobago: University of the West Indies.

Kirpalani, M.J., M.G. Sinanan, S.M. Fameshwar \& L.F. Seukaran 1945. Indian

Centenary Review. Port of Spain, Trinidad: Guardian Commercial Printery.

Lynch, J.W. 2017. St. Joseph First Presbyterian Church Hosts $150^{\text {th }}$ Celebration. TnT Mirror Newspaper (Weekend Edition).

Mahabir, K. \& S. Chand 2015. The Phenomenon of Ramleela/ Ramlila Theatre in Trinidad. Nidan: International Journal for the Study of Hinduism 27, 1\&2: 1-20.

Mahabir, K. 2007. Indian Contribution to the West Indies/ Caribbean. In Dubey, A. (ed.): Contributions of PIO to their Countries of Adoption. (In press).

Mahabir, K. 2017. Editorial: Indian Arrival Day in Trinidad \& Tobago. Indian Arrival Day Commemorative Magazine 18,1.

Mahase, R. 2017. Towards the End of the Indian Indentureship System Part -

I. Guardian. Available at: http://guardian.co.tt/news/2017-0312/towards-end-indian-indentureship-system\%E2\%80\%94part-1.

(Accessed on 20 October 2017).

Mahase, R. n.d. 'Abolish Indenture' and the Indian Nationalist Discourse in Early $20^{\text {th }}$ Century. Available at: https://www.academia.edu/4094172/ ABOLISH_INDENTURE_AND_THE_INDIAN_NATIONALIST_DIS 
COURSE_IN_THE_EARLY_20TH_CENTURY. (Accessed on 20 October 2017).

Ministry of External Affairs 2017. Pravasi Bharatiya Divas, Government of India. Available at: http://www.mea.gov.in/pravasi-bharatiya-divas.htm (Accessed on 22 October, 2017)

Mitchell, K. 1997. Different Diasporas and the Hype of Hybridity. Environment and Planning D: Society \& Space 15, 533-53.

Mohabir, N. 2013. The Ebb and Flow of Arriving. In the Diaspora. Available at: https://www.stabroeknews.com/2013/features/in-the-diaspora/04/29/ the-ebb-and-flow-of-arriving/. (Accessed on 18 October 2017).

Mohanty, S.S. 2014. Indian Diaspora in the West Indies: An Overview and an Insight. In Mohanty, S.S. (ed.): Indian West Indian through the Writings of V.S. Naipaul: Socio-cultural and Political Dimensions of Indian Diaspora. New Delhi: Jawaharlal Nehru University.

Murali, A. 2015. Tracing the Roots through Changing History: The Story of East Indians in Trinidad. In Murali, A. (ed.): India in the Caribbean: Socio-Cultural Moorings of Diaspora. New Delhi: India Empire Publications.

Naidu, J. 2007. Retention and Transcultural of Hinduism in the Caribbean.

Guyana Journal Available at: http://www.guyanajournal.com/hinduism_ caribbean.html. (Accessed on 23 October 2017).

Niehoff, A. \& J. Niehoff 1960. East Indians in the West Indies. Milwaukee:

Milwakaukee Public Museum Publications in Anthropology.

Parmasad, K.V. 1999. Ramleela and Hosay: Contestation on the Periphery:

Towards 2000 - Models for Multi-Cultural Arts Education. Caribbean

Quarterly 45, 2/3: 67-70.

Riggio, M.C. 2010. Performing in the Lap and at the Feet of God: Ramleela in Trinidad, 2006 - 2008. TDR: The Drama Review 54, 1: 106 - 149.

Samaroo, B. 2015. From Girmityas to Nation-builders: The Indo-Caribbean Experience. In Murali, A. (ed.): India in the Caribbean: Socio-Cultural Moorings of Diaspora. New Delhi: India Empire Publications.

Sanderson Committee Report 1910. London.

Shakleton, M. 2008. Diasporic Literature and Theory. Where Now? UK:

Cambridge Scholars Publishing.

Vertovec, S. 1992. Hindu Trinidad: Religion, Ethnicity and Socio-Economic Change. Warwick, UK: Centre for Caribbean Studies Publications. Hong Kong: McMillan Education Limited. 
India and Trinidad \& Tobago: Diaspora Building and Diaspora Integration

Vertovec, S. 2000. 'Official' and 'Popular' Hinduism. In Vertovec, S. (ed.): The Hindu Diaspora: Comparative Patterns. New York: Routledge.

Viswanathan, R. 2005. Business with Latin America. New Delhi: Exim Bank. Winer, L. 2008. Dictionary of English/Creole of Trinidad \& Tobago: On Historical Principles. Canada: Mc-Gill Queen University Press.

Wood, D. 1968. Trinidad in Transition: The Years after Slavery. London: Oxford University Press.

Susan Julia Chand Directorate of Research and Innovation, and Anthropology School of Social Sciences University of the Southern Caribbean (USC), Trinidad susan.chand@gmail.com 